\title{
Baseline trace metals in gastropod mollusks from the Beagle Channel, Tierra del Fuego (Patagonia, Argentina)
}

\author{
Marcelo Enrique Conti · Jorge Stripeikis • \\ Maria Grazia Finoia - Mabel Beatriz Tudino
}

Accepted: 6 February 2012/Published online: 18 February 2012

(C) Springer Science+Business Media, LLC 2012

\begin{abstract}
With the aim to evaluate the mollusk Nacella (P)magellanica as biomonitor of elemental pollution in seawater of the Beagle Channel, more than one hundred individuals of the gastropod were sampled, separated in viscera and muscle, and then examined with respect to the accumulation of $\mathrm{Cd}, \mathrm{Cr}, \mathrm{Cu}, \mathrm{Ni}, \mathrm{Pb}$ and $\mathrm{Zn}$. Collection was performed in seven strategic locations along $170 \mathrm{~km}$ of the coastal area of the Beagle Channel (Tierra del Fuego, Argentina) in two campaigns during 2005 and 2007. Samples of surrounding seawater in the different sites were obtained and tested for the same metals as well. The accumulation capacity of Nacella $(P)$ magellanica and thus its aptitude as biomonitor, was evaluated through the calculus of the preconcentration factors of the metals assayed. A discussion involving the comparison with other mollusks previously tested will be given. Several statistical approaches able to analyze data with environmental purposes were applied. Non parametric univariate tests such as Kruskal-Wallis and Mann-Whitney were carried out to
\end{abstract}

M. E. Conti ( $\square)$

Department of Management, University of Rome, Via del Castro Laurenziano 9, 00161 Rome, Italy

e-mail: marcelo.conti@uniroma1.it

\section{E. Conti}

International Academy of Environmental Sciences (IAES),

Campo della Chiesa 3, Sant'Elena, 30122 Venice, Italy

J. Stripeikis - M. B. Tudino

INQUIMAE, Departamento de Química Inorgánica, Analítica y

Química Física, Facultad de Ciencias Exactas y Naturales,

Universidad de Buenos Aires, Buenos Aires, Argentina

M. G. Finoia

Istituto Superiore per la Protezione e la Ricerca Ambientale,

Via di Casalotti 300, 00166 Rome, Italy assess the changes of the metal concentrations with time (2005 and 2007) in each location. Multivariate methods (linear discriminant analysis on PCA factors) were also applied to obtain a more reliable site classification. Johnson's probabilistic method was carried out for comparison between different geographical areas. The possibility of employing these results as heavy metals' background levels of seawater from the Beagle Channel will be debated.

Keywords Limpets - Trace metals accumulation . Beagle channel · Environmental significance

\section{Introduction}

Using organisms as biological monitors for metal pollution in marine environment is a well established subject (Rainbow and Phillips 1993; Conti 2008). Biological monitoring methods lead to a remarkable reduction in time and costs if compared with direct analysis in waters, mainly because the amounts of metals to be measured are larger and could escape from the more complex ultratrace analysis domain. Additionally, the chemical analysis of tissues of organisms (i.e., mollusks) supplies evidence of the integrated bioavailability of trace metals in the marine environment over time. In fact, they respond only to the seawater fraction presenting a clear and improved ecotoxicological relevance (Rainbow and Phillips 1993).

Mollusks are often used as biomonitors for trace metal pollution in seawater as they meet the requisites for a good biomonitor as stated elsewhere (Conti et al. 2002, 2005; Deudero et al. 2009).

Recent studies on gastropod mollusks from the marine Mediterranean areas have contributed to a better knowledge on elemental accumulation of these species and at the 
same time have permitted to evaluate probable human health risks derived from their consumption (Ahn et al. 1999; Conti et al. 2007a; Conti and Finoia 2010). Even though the amounts of accumulated chemical species revealed themselves as harmless for human ingest, they constitute an index of human exposure as these mollusks (e.g., patellid limpets) are an usual indigenous food amongst the habitants of the area (Conti and Finoia 2010).

For a baseline study of trace metals in the Beagle Channel (Fig. 1), the limpet Nacella (Patinigera) magellanica (Gmelin 1971) seemed to be suitable as biomonitor as it is well distributed in the middle and upper intertidal zones of the Beagle Channel (Conti et al. 2006). The limpet lives on rocky substrata of tidelands and tolerates fairly long periods of time outside of the water. Since its diet is based on algae and vegetable deposits scratched from the rocks (Morriconi 1999; Conti et al. 2006), it takes metals from the food (Ahn et al. 2002) making presumable its capacity for elemental accumulation.

Consequently, it was selected to fulfill the objectives of this study: (1) to evaluate Nacella (P)magellanica as a possible biomonitor of pollution of $\mathrm{Cd}, \mathrm{Cr}, \mathrm{Cu}, \mathrm{Ni}, \mathrm{Pb}$ and $\mathrm{Zn}$ in the Beagle Channel, (2) to search for strategic points in the Beagle Channel able to provide background contamination levels, (3) to analyze the variation of the contamination with time, (4) to infer the daily intake of heavy metals through the consumption of these gastropod mollusks in the diet, and finally, (5) to compare the baseline levels of contamination in the Beagle Channel ecosystem with marine baseline sites in the Tyrrhenian Sea (Italy).

This study follows the first one conducted in the same area by using the bivalve Mytilus chilensis (Conti et al. 2011) as biomonitor for baseline trace metals in the Beagle Channel. In this case, we present the results obtained for the determination of the metals listed above in samples of muscle and viscera of Nacella (P)magellanica collected in the same locations during 2005 and 2007. Metals concentrations in the surrounding seawater are presented as well. Different statistical approaches able to evaluate the environmental meaning of the results will be also shown. Comparison with similar studies in the literature will be provided and the main findings fully debated.

\section{Materials and methods}

\section{Study area}

Beagle Channel is a strait in Tierra del Fuego, near the southern tip of South America. The channel has high ecological relevance and is about $240 \mathrm{~km}$ long and between 5 and $14 \mathrm{~km}$ wide. It separates Isla Grande de Tierra del Fuego from several smaller islands in the south. It owes its name to the British ship Beagle, employed by Charles Darwin to explore the area between 1833 and 1834. The main urban settlement in Tierra del Fuego is the city of Ushuaia that is the southernmost city of the world with ca. 60,000 inhabitants (Conti et al. 2011). Ushuaia is the most important port for the Antartic tourism and maritime traffic. Tierra del Fuego has a unique ecosystem and it is characterized by a wide range of wildlife and biodiversity (Conti et al. 2009, 2012, Pino et al. 2010). Except for the case of Ushuaia Harbour, the six remaining sampling sites were carefully selected as examples of supposedly unpolluted areas along the Beagle Channel (Conti et al. 2011).

\section{Collection of samples}

Mollusks were collected in two sampling campaigns carried out on September 2005 and September 2007. Both campaigns respected the same geographical locations. Figure 1 shows the seven selected stations situated along $170 \mathrm{~km}$ of the Beagle Channel (Conti et al. 2011).

Fig. 1 The study area

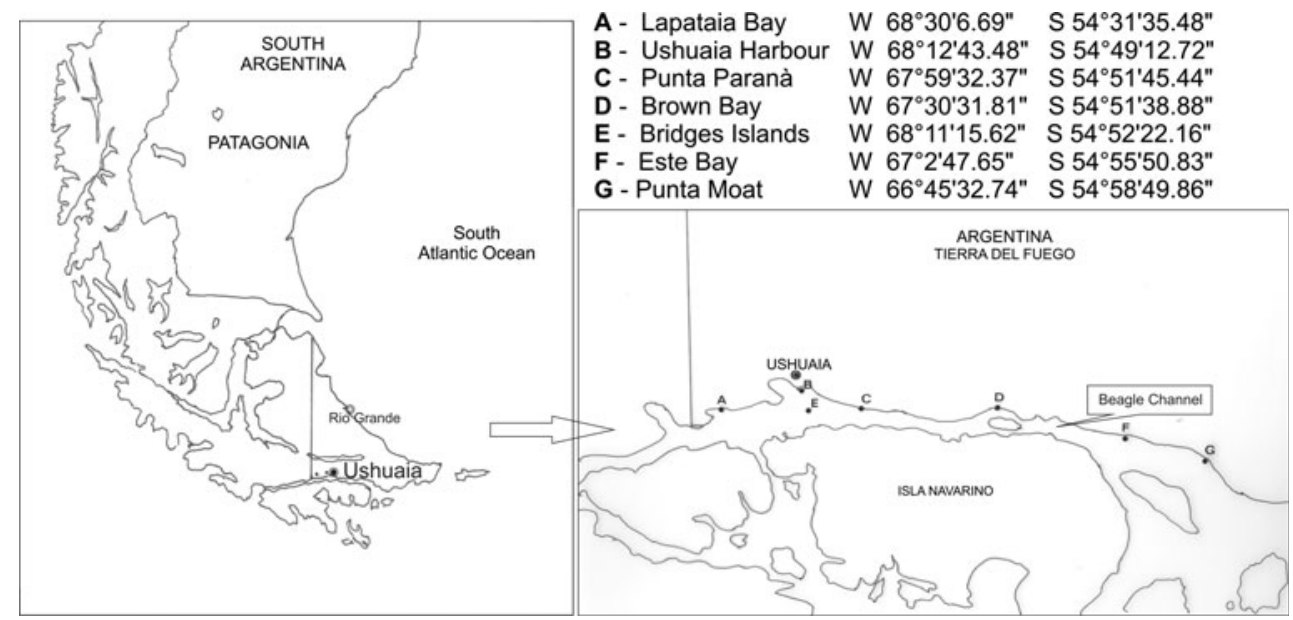


Individuals of $N .(P)$ magellanica $(n=175)$ were collected in the tidal zone at the same depth and distance from the shoreline in 2005 ( $n=105)$ and $2007(n=70)$ sampling campaigns. The sampling campaign in 2005 was 15 individuals each site $(15 \times 7=105)$; and 10 individuals each site $(10 \times 7=70)$ in 2007 . Afterwards, they were depurated $(t=24 \mathrm{~h})$ with filtered seawater from the same site of collection of samples. Shell lengths and weights of the samples were kept fairly constant in order to reduce variability due to size (Conti 2008).

All individual samples were separated in muscle and viscera, placed in polyethylene bags, ice deep-frozen and transported to the laboratory. Soft parts were taken out of the shell using plastic tools (hammer and spatula) to prevent metal contamination, and then they were rinsed with deionized MilliQ water (DIW) to remove residues of shell (for sample treatment details see Conti et al. 2010).

Drying, mineralization and analyses of mollusks samples

Samples of muscle and viscera (400-800 mg) were previously dried, homogenized and treated with $8 \mathrm{~mL}$ of $70 \%$ (w/w) nitric acid Suprapur (Merck) and $2 \mathrm{~mL}$ of $30 \%$ (w/w) hydrogen peroxide Suprapur (Merck) in PTFE $^{\circledR}$ vessels. The microwave (MW) digestion system (CEM, MDS-2000) (CEM) was used for the mineralization process. The significance of the MW digestion methods in biological and environmental matrices was discussed elsewhere (Bocca et al. 2007; Pino et al. 2007). The mineralization program was run according to the manufacturer. The digested samples were made up to $25 \mathrm{~mL}$ with DIW.

Heavy metals were determined in both, mineralized muscle and viscera samples, using atomic absorption spectrometry with graphite furnace atomization (GFAAS, Shimadzu 6800) for $\mathrm{Cd}, \mathrm{Cr}, \mathrm{Ni}$ and $\mathrm{Pb}$, and flame atomic absorption spectrometry (FAAS) for $\mathrm{Zn}$ and $\mathrm{Cu}$. Instrumental parameters and graphite furnace programs were those provided by the manufacturer (Conti et al. 2011). Traceability of results was obtained from the analysis of the certified reference material Antarctic krill MURSTISS-A2 (Italian Research Program in Antarctica). The mean recovery percentages (five replicates) were: $\mathrm{Cd}$ : $93.4 \pm 2.7 \%$; Cr: $98.1 \pm 1.0 \%$; Cu: $101.1 \pm 1.3 \%$; Ni: $98.5 \pm 2.5 \%$; Pb: $96.5 \pm 0.6 \%$ and $\mathrm{Zn}: 102.1 \pm 2.9 \%$.

Detection limits and dry weight determination

The Limit of Detection (LOD) is the lowest concentration level that can be determined to be statistically different from a blank with a $99 \%$ of confidence. The LOD is mathematically defined as equal to three times the standard deviation of the results for a series of ten replicate blanks $(3 \sigma \mathrm{b}, n=10)$.

Detection limits (LODs) $(3 \sigma \mathrm{b}, n=10)$ were: $\mathrm{Cd}$ : $0.0001 \mathrm{mg} \mathrm{L}^{-1}$; Cr: $0.0002 \mathrm{mg} \mathrm{L}^{-1}$; Cu: $0.020 \mathrm{mg} \mathrm{L}^{-1}$; Ni: 0,005 mg L ${ }^{-1}$; $\mathrm{Pb}: 0.001 \mathrm{mg} \mathrm{L}^{-1}$ and $\mathrm{Zn}: 0.010 \mathrm{mg} \mathrm{L}^{-1}$.

A separate study was conducted for dry weight determination by oven drying at $105^{\circ} \mathrm{C}$ up to constant weight (five replicates for each location in the two sampling campaigns $(n=70)$.

All chemicals used throughout these experiments were ultrapure grade.

Collection of water samples and heavy metals determination

Marine water samples were collected in both sampling campaigns (seven samples each) at $2 \mathrm{~m}$ depth and at the same sites of mollusks collection (see Fig. 1). Two samples of $1 \mathrm{~L}$ each were collected, preserved and stored in PFTE bottles in each one of the locations under study $(n=28)$. Thus, we have performed reproducibility tests (true replicates). Repetitivity tests were also performed as several measurements of each one of the analytes in the same sample were performed.

Salinity measurements were performed as changes in the ionic strength could affect elemental speciation (Turner et al. 2008; Conti et al. 2010).

Filtration was performed in the laboratory where water samples were passed through an acid pre-cleaned membrane filter of $0.45 \mu \mathrm{m}$. Afterwards, they were acidified and stored at $4^{\circ} \mathrm{C}$ for soluble metals determination.

For the determination of heavy metals in seawater samples, the resin Amberlite XAD-16 (Narin and Soylak 2003) impregnated with 1-(2-pyridylazo) 2-naphtol (PAN) was used for the solid phase extraction (SPE) of $\mathrm{Cu}, \mathrm{Pb}$, $\mathrm{Cd}, \mathrm{Ni}$ and $\mathrm{Zn}$. In this way both, the pre-concentration of the analytes as well as the isolation from the saline matrix which seriously interferes the analytical determinations, were automatically performed. For doing this a flow injection system carrying an acrylic microcolumn filled with the resin (about $20 \mu \mathrm{L}$ bed volume) was coupled to the atomic absorption spectrometer as described in a previous paper (Conti et al. 2011). Elution was performed with $500 \mu \mathrm{L}$ of HNO3 $5 \% \mathrm{~m} / \mathrm{v}$ in order to obtain quantitative recovery of the metals. Subsampling of the eluate was needed as no more than $100 \mu \mathrm{L}$ are supported by the atomizer employed here (Pedro et al. 2008).

The accuracy of the analytical method was validated by the employment of the certified standard reference material Trace elements in Water (1643e, NIST). The experimental values obtained for metals concentration were in good agreement (95\% confidence level) with the certified ones. 
Calculus of the concentration factors $(\mathrm{CFs})$

Once heavy metals concentrations on both, mollusks and seawater samples were determined, the concentration factor was calculated as the ratio between the mean concentration of each one of the metals in the organism (Co) expressed in $\mu \mathrm{g} \mathrm{g}^{-1}$ dry weight (d.w.) and the mean concentration in seawater (Csw) expressed in $\mathrm{ng} \mathrm{L}^{-1}$. CFs were always referred to the soluble fraction in seawater.

\section{Statistical analysis}

Several statistical approaches can be used for data analysis applied to environmental studies (Conti et al. 2005, 2007b). The changes of the metal concentrations with time in each site was evaluated by using univariate tests such as KruskalWallis $(\mathrm{K}-\mathrm{W})$ and Mann-Whitney $(\mathrm{M}-\mathrm{W})$ tests. The $\mathrm{K}-\mathrm{W}$ one-way analysis of variance by ranks is a non-parametric method for testing equality of population medians among groups. In this case $\mathrm{K}-\mathrm{W}$ was employed to verify the differences of metal concentrations between the two sampling campaigns. The $\mathrm{M}-\mathrm{W} U$ test is a non-parametric statistical hypothesis test for assessing whether two independent samples of observations have equally large values. It was employed here to carry out unpaired comparisons. The correction of the first-type error was applied by using Bonferroni's correction at significance level of $p=0.007$ (among sites) and at $p=0.01$ (variation with time).

Data were standardized and analyzed by multivariate techniques such as principal component analysis (PCA) and linear discriminant analysis (LDA) on PCA factors (Conti et al. 2007b; Zhou et al. 2007). The latter was validated by applying Monte-Carlo test on LDA (Test of the sum of a discriminant analysis eigenvalues divided by the rank, non parametric version of the Pillai's test) (Chessel et al. 2004). A number of 999 permutations were simulated: the $p$-value was highly significant when differences between groups were detected.

Linear discriminant analysis on PCA factors was applied in order to discriminate sampling sites based on $N$. magellanica metal contents in viscera. Data obtained in both sampling campaigns (2005 and 2007) were employed. Multivariate analysis was not applied to muscle because the levels of $\mathrm{Cu} \mathrm{Ni}$ and $\mathrm{Pb}$ fell below the limits of detection (LOD). Data analysis was performed by Ade4 package, program R.2.4.1 and SPSS 12.1. Description of PCA and LDA techniques are reported elsewhere (Conti and Mecozzi 2008).

Finally, we compared our results to those obtained for other patellid limpet (i.e., Patella caerulea) in the Italian seas. We used the normality ranges defined by Johnson's method (Johnson 1949; Giovanardi et al. 2006) for P. caerulea (Conti and Finoia 2010) which was sampled along a $800 \mathrm{~km}$ transect in the Tyrrhenian Sea, with the aim to test these normality ranges (i.e., baseline levels) and to compare them with other ecosystems (i.e., Beagle Channel).

Data analysis was perfomed by SuppDists package (Wheeler 2009). For this purpose our metal data were standardized using 66 and $34 \%$ of mean weight for muscle and viscera in the whole tissue respectively $(n=70)$.

\section{Results}

Table 1 shows mean metal concentrations in the two sampling campaigns (2005 and 2007) $\left(\mu \mathrm{g} \mathrm{g}^{-1}\right.$ dry weight) in muscle and viscera of Nacella (Patinigera) magellanica (mean $\pm \mathrm{SD}$ ), mean metal concentrations (mean $\pm \mathrm{SD}$ ) in coastal seawater samples (ng $\left.\mathrm{L}^{-1}\right)(n=7$ stations), and Concentration Factors ( $\mathrm{CFs}$ ) in muscle and viscera calculated as described above.

The muscle concentrations for the metals in the two sampling campaigns were in the range $0.90-10.10 \mu \mathrm{g} \mathrm{g}^{-1}$ for $\mathrm{Cd}$; $<0.07-2.10 \mu \mathrm{g} \mathrm{g}^{-1}$ for $\mathrm{Cr}$ and 19.1-55.0 $\mu \mathrm{g} \mathrm{g}^{-1}$ for $\mathrm{Zn}$. $\mathrm{Cu}, \mathrm{Ni}$ and $\mathrm{Pb}$ were always below the LODs of the instrumental technique (i.e., $<4.0,<0.30$ and $<0.10 \mu \mathrm{g} \mathrm{g}^{-1}$, respectively). Metals determinations in viscera for both sampling campaigns, showed concentrations in the range $1.60-24.20 \mu \mathrm{g} \mathrm{g}^{-1}$ for $\mathrm{Cd}$; $0.13-12.10 \mu \mathrm{g} \mathrm{g}^{-1}$ for $\mathrm{Cr}$; $<4.0-51.80 \mu \mathrm{g} \mathrm{g}^{-1}$ for $\mathrm{Cu}$; 2.50-22.70 $\mu \mathrm{g} \mathrm{g}^{-1}$ for $\mathrm{Ni}$; $<0.10-10.40 \mu \mathrm{g} \mathrm{g}^{-1}$ for $\mathrm{Pb}$ and $40.9-159.0 \mu \mathrm{g} \mathrm{g}^{-1}$ for $\mathrm{Zn}$.

\section{Variation of the metal contamination}

Figures 2, 3, 4, 5 show box and whiskers plots of the metal concentrations (raw data) contents in muscle and viscera of the mollusks in the selected sites for both sampling campaigns (2005 and 2007). The whiskers plots of muscle samples (Fig. 4) are not reported for $\mathrm{Cu}, \mathrm{Ni}$ and $\mathrm{Pb}$ since their concentrations fell below the LODs. The black line is the median value, the boxes represent the first and the third quartile, whilst the whiskers are set to \pm 1.5 times the interquartile interval. These values should match the minimum and the maximum values in absence of outliers and/or extreme values.

$\mathrm{Cd}$ showed no significant bioaccumulation differences for both muscle and viscera in both sampling campaigns (Fig. 2; M-W test: not significant). Lapataia (A) and Punta Moat (G) showed higher significant levels (K-W, $p<0.007)$ of $\mathrm{Cd}$ than the other sites. The Ushuaia Harbour (B) showed the lower Cd levels $(\mathrm{K}-\mathrm{W}, p<0.007)$ in muscle and viscera in comparison to the other sites (Fig. 2). These results are in agreement with those reported in a previous paper (Conti et al. 2011) where the bivalve M. chilensis was used as biomonitor in the same sites. Nonetheless, this fact is still surprising and needs further 
Table 1 Mean metal concentrations in the two sampling campaigns (2005 and 2007) ( $\mu \mathrm{g} \mathrm{g}^{-1}$ d.w.) in muscle and viscera samples of Nacella (Patinigera)magellanica (mean $\pm \mathrm{SD}$ ), mean metal concentrations in

\begin{tabular}{lllllll}
\hline & $\mathrm{Cd}$ & $\mathrm{Cr}$ & $\mathrm{Cu}$ & $\mathrm{Ni}$ & $\mathrm{Pb}$ & $\mathrm{Zn}$ \\
\hline Muscle $(n=175)$ & $3.97 \pm 2.45$ & $0.20 \pm 0.28$ & $<4.00$ & $<0.30$ & $0.13 \pm 0.16$ & $30.7 \pm 5.9$ \\
Viscera $(n=175)$ & $8.22 \pm 4.01$ & $3.16 \pm 2.29$ & $15.16 \pm 8.45$ & $7.63 \pm 4.07$ & $1.23 \pm 1.57$ & $96.2 \pm 25.4$ \\
Seawater $(n=28)$ (soluble) & $<18$ & - & $311 \pm 233$ & $<100$ & $1,176 \pm 1,243$ & $768 \pm 369$ \\
$\mathrm{CFs}^{\mathrm{a}} \times 10^{3}$ (muscle) & $227.8^{\mathrm{b}}$ & - & - & - & 0.114 & 41.3 \\
$\mathrm{CFs}^{\mathrm{a}} \times 10^{3}$ (viscera) & $471.7^{\mathrm{b}}$ & - & 50.3 & $78.8^{\mathrm{b}}$ & 1.08 & 129.4
\end{tabular}

${ }^{\mathrm{a}} C F=C \mathrm{o} / C \mathrm{sw}$, where $C \mathrm{o}=$ mean concentration in the organism $\left(\mu \mathrm{g} \mathrm{g}^{-1}\right.$ d.w.) and $C \mathrm{sw}=$ mean concentration in seawater $\left(\mathrm{ng} \mathrm{L}^{-1}\right)$. $\mathrm{CFs}$ are referred to the soluble fraction of seawater. Mean salinity recorded during sampling: $33 \pm 1 \mathrm{NaCl} / \mathrm{liter}$

${ }^{\mathrm{b}} \mathrm{CFs}$ are here intended as a minimum possible $\mathrm{CF}$ value obtained for Nacella samples

Fig. 2 Box and whiskers plots of $\mathrm{Cd}$ concentrations determined in muscle and viscera of $N$. magellanica in the selected sites and in the two sampling campaigns (2005 and 2007). See Fig. 1 for sites description
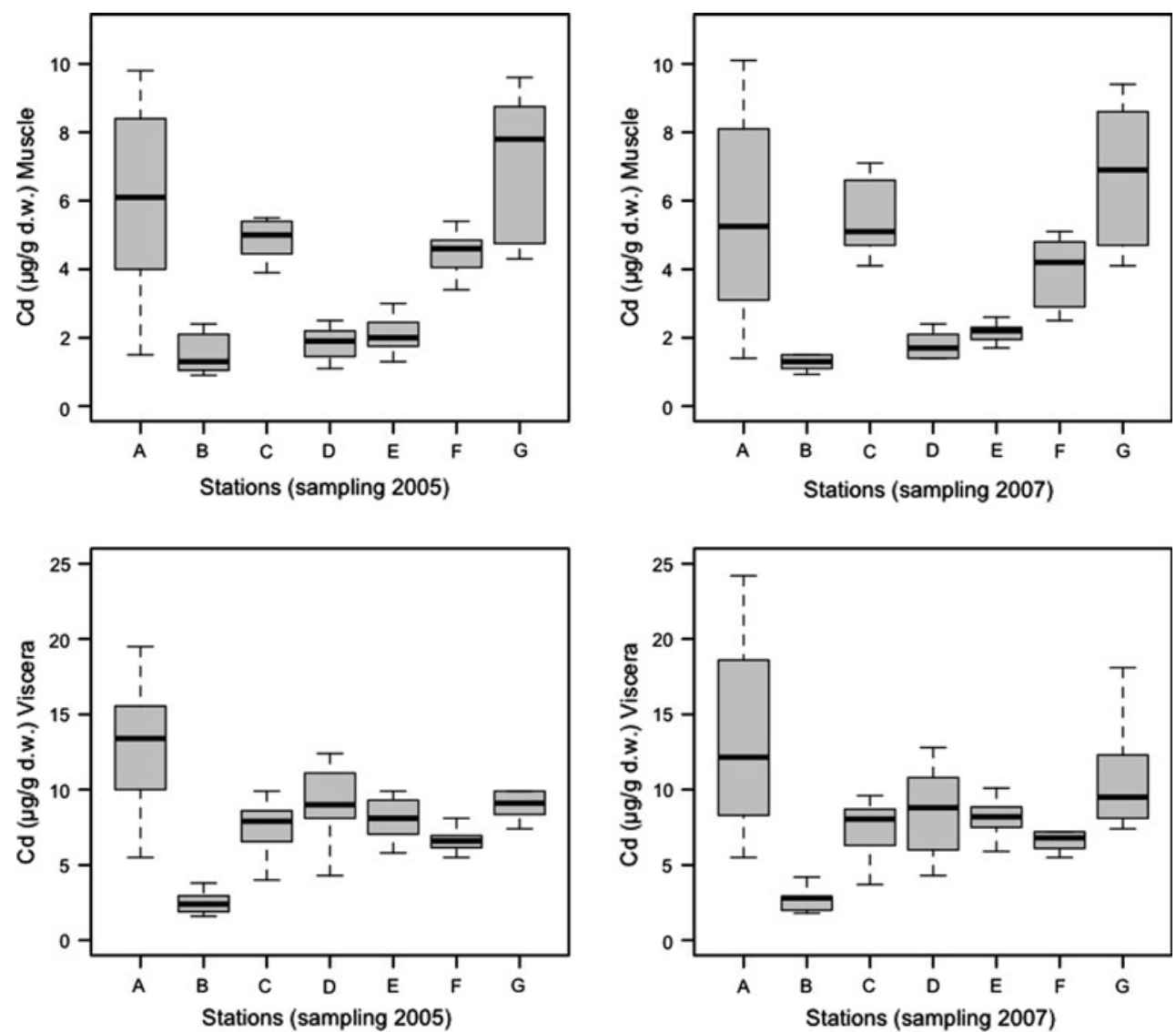

investigation. As stated in previous works of the authors, may be cadmium speciation is different in each location yielding to differences in the biovailability of the metal (Muse et al. 2006; Conti et al. 2011).

$\mathrm{Cr}$ in muscle samples showed higher levels $(\mathrm{M}-\mathrm{W}$, $p<0.007)$ in 2007 than in 2005 sampling campaign for the sites Ushuaia Harbour (B) and Punta Paranà (C) (Fig. 3). On the contrary, the $\mathrm{M}-\mathrm{W}$ test $(p<0.03)$ revealed lower $\mathrm{Cr}$ bioaccumulation levels in viscera samples in 2007 than those of 2005 sampling campaign in Ushuaia Harbour (B), Brown Bay (D) and Punta Moat (G) sites. Punta Paranà (G) increased its $\mathrm{Cr}$ levels $(\mathrm{M}-\mathrm{W}, p<0.01)$ in 2007 (Fig. 3).

No significant differences (M-W: n.s.) were observed for $\mathrm{Ni}$ in viscera samples between the two sampling campaigns (Fig. 4 middle). Lapataia Bay (A) and Punta Paranà (C) showed the higher levels of $\mathrm{Ni}$ while Punta Moat site showed the lowest $(\mathrm{K}-\mathrm{W}, p<0.007)$. 
Fig. 3 Box and whiskers plots of $\mathrm{Cr}$ concentrations determined in muscle and viscera of $N$. magellanica in the selected campaigns (2005 and 2007). See Fig. 1 for sites description sites and in the two sampling
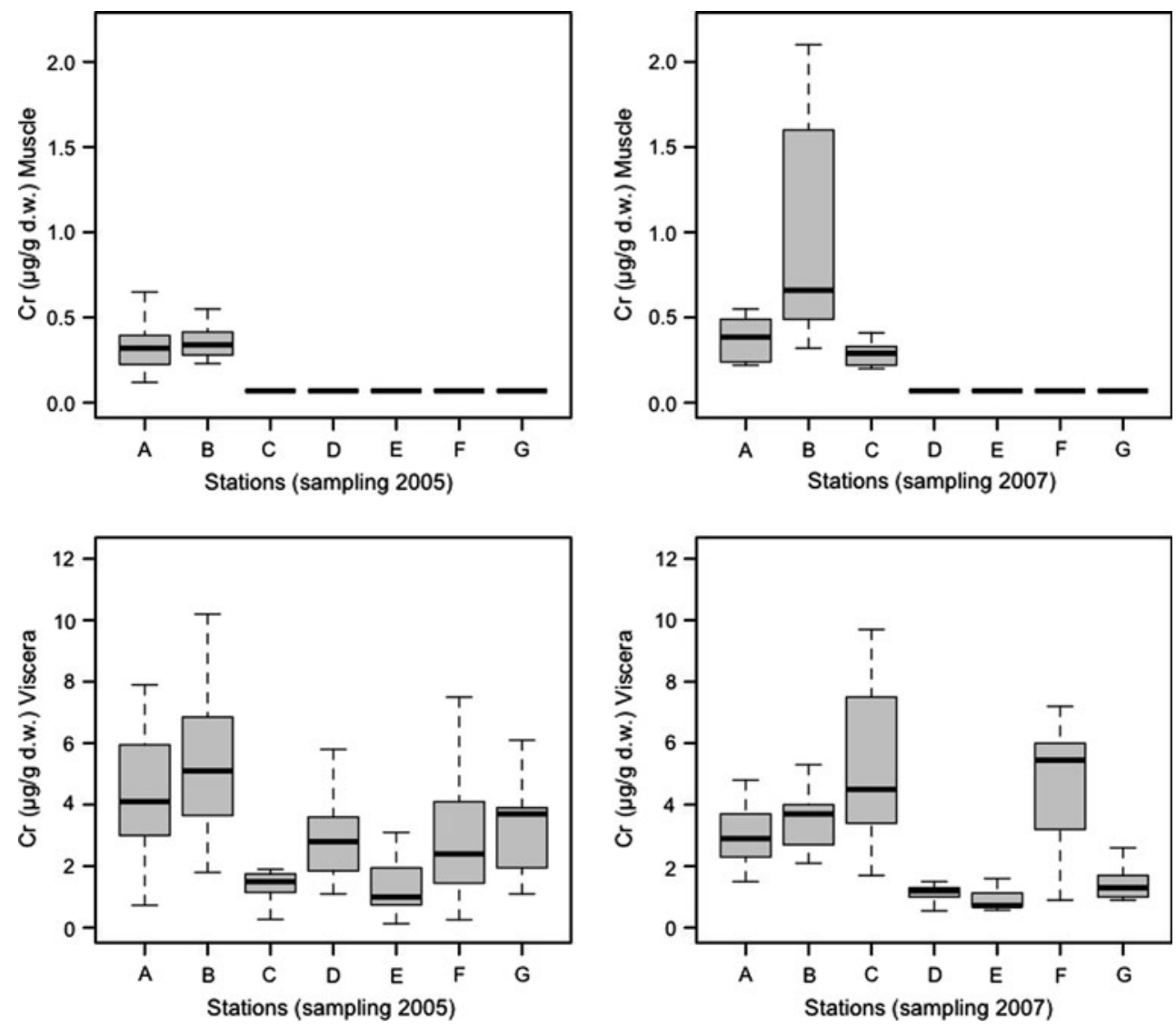

Fig. 4 Box and whiskers plots of $\mathrm{Cu}, \mathrm{Ni}, \mathrm{Pb}$ concentrations determined in viscera of $N$. magellanica in the selected sites and in the two sampling campaigns (2005 and 2007). See Fig. 1 for sites description
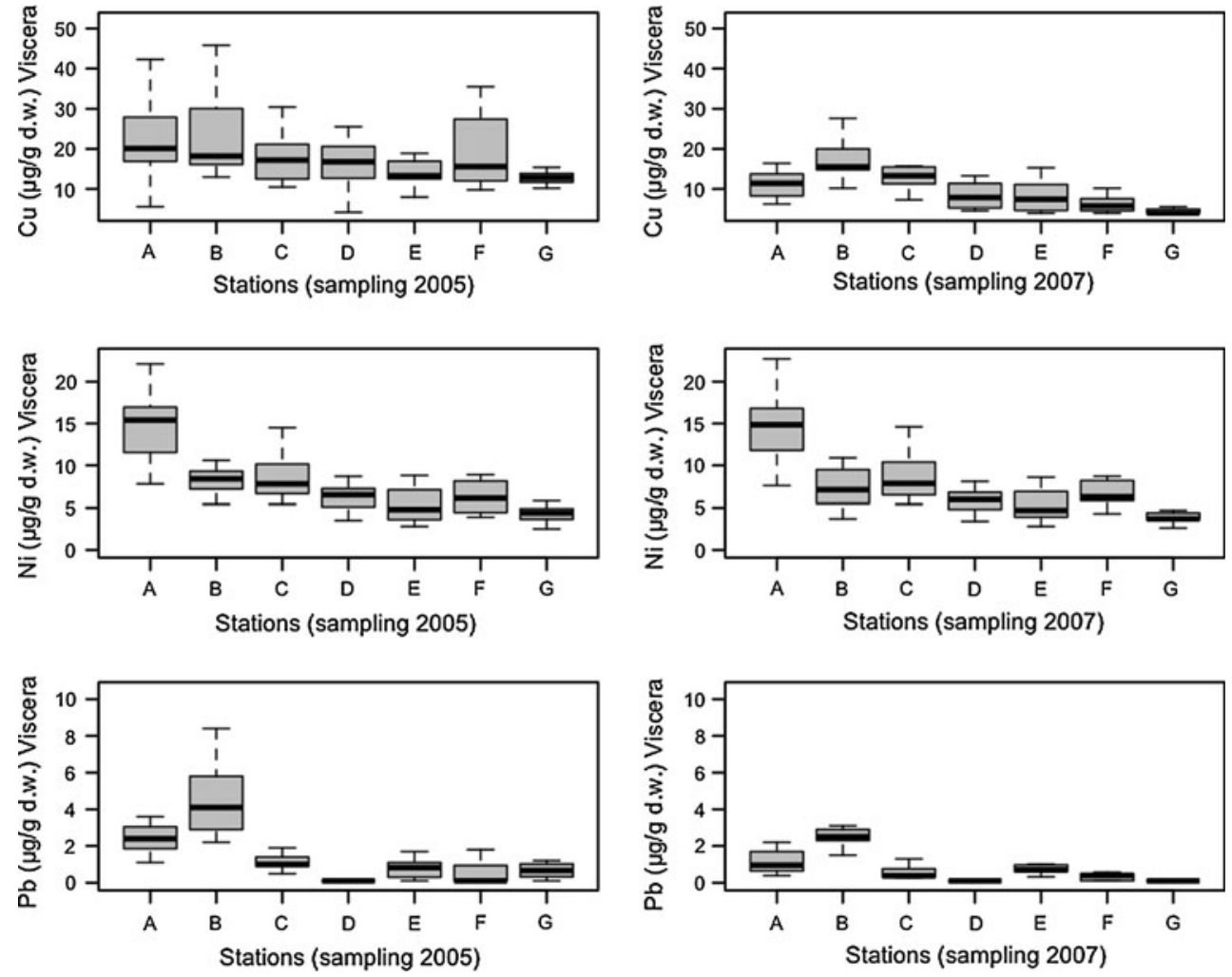

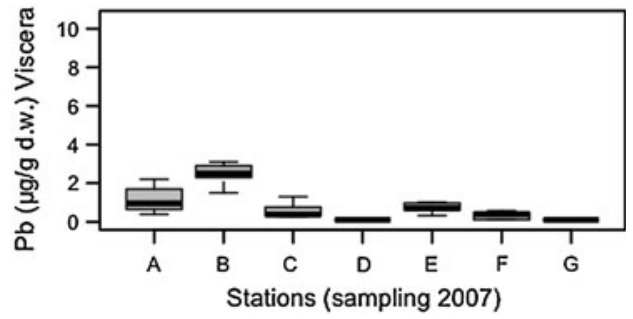


Fig. 5 Box and whiskers plots of $\mathrm{Zn}$ concentrations determined in muscle and viscera of $N$. magellanica in the selected sites and in the two sampling campaigns (2005 and 2007). See Fig. 1 for sites description
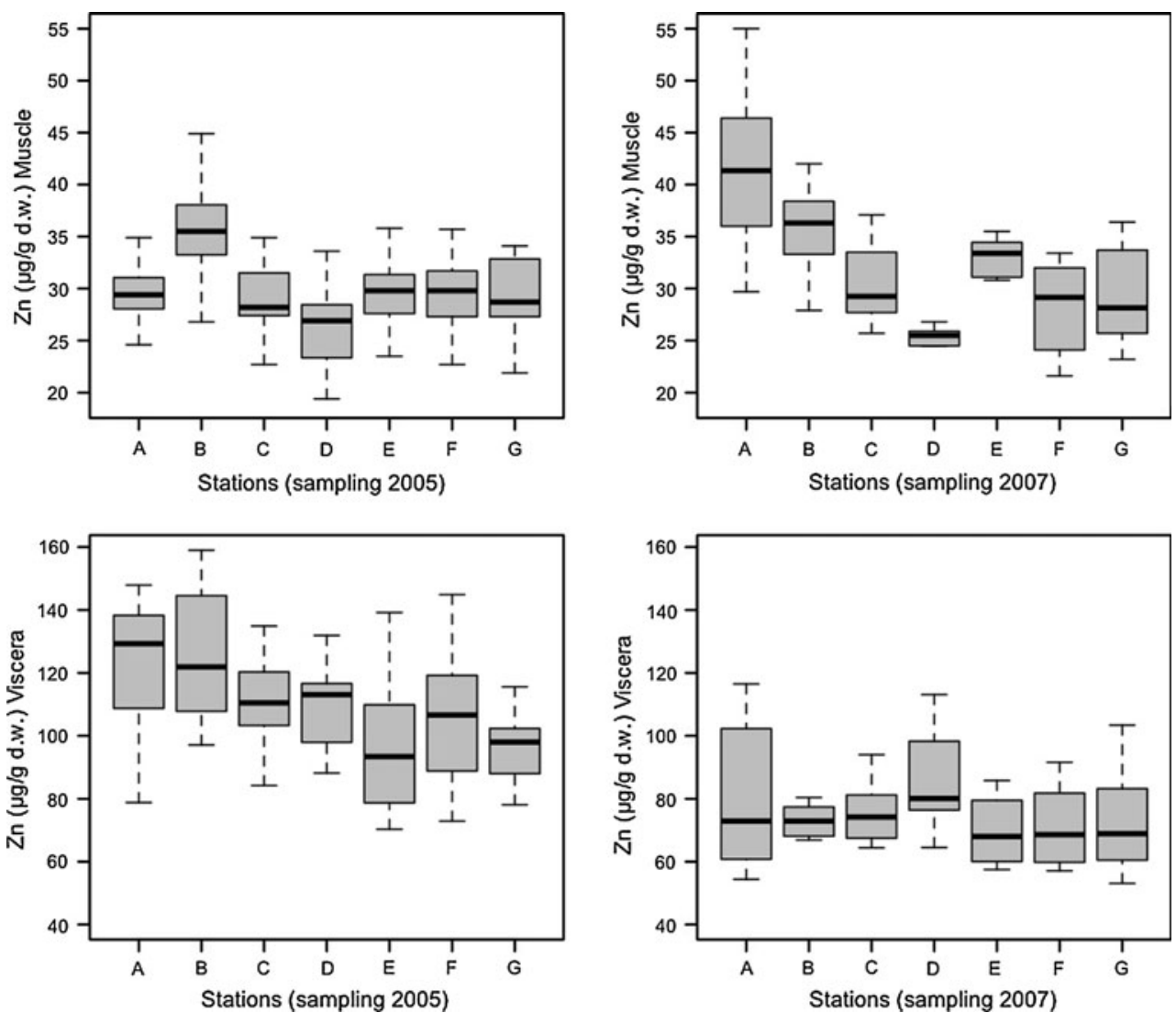

$\mathrm{Pb}$ levels in $N$. magellanica viscera samples decreased significantly (M-W, $p<0.01$ ) from 2005 to 2007 in Lapataia (A), Ushuaia Harbour (B), Punta Paranà (C) and Punta Moat (G) sites (Fig. 4 bottom). Lapataia Bay (A) and Ushuaia Harbour (B) showed the higher levels of $\mathrm{Pb}(\mathrm{K}-\mathrm{W}$, $p<0.007)$, while Brown Bay (D) and Punta Moat (G) showed the lowest $\mathrm{Pb}$ levels $(\mathrm{K}-\mathrm{W}, p<0.05)$ (Fig. 4 bottom).

The levels of $\mathrm{Zn}$ in muscle samples were higher in 2007 sampling campaign in Lapataia (A) and Bridges Islands (E) in comparison to 2005 samples $(\mathrm{M}-\mathrm{W}, p<0.01)$ (Fig. 5 top). On the contrary, $\mathrm{Zn}$ levels in viscera samples decreased significantly $(\mathrm{M}-\mathrm{W}$ test $p<0.01)$ in 2007 (Fig. 5 bottom). Since the whole amount of accumulated $\mathrm{Zn}$ (viscera + muscle) remained practically constant in both sites and during both campaigns, it is reasonable to think that there is no site undoubtedly more contaminated than the other or, at least, that essential elements like $\mathrm{Zn}$ are not good for discrimination purposes.

Sites classification

With the aim to obtain more reliable results multivariate techniques were applied. Figure 6 shows LDA on PCA results of sampling station factors for the two sampling campaigns in $N$. magellanica viscera metal data (2005-2007). $75.5 \%$ of the total variability is explained by the first two canonical axes. LDA resulted significant (Monte-Carlo test $0.29 ; p=0.001$ ) confirming sites' discrimination. N. magellanica viscera samples collected in the Ushuaia Harbour (B) showed the highest $\mathrm{Pb}, \mathrm{Cu}, \mathrm{Cr}$ and $\mathrm{Zn}$ levels and the lowest $\mathrm{Cd}$ concentrations. Moreover, Lapataia (A) samples showed clearly higher concentrations of $\mathrm{Ni}$ and $\mathrm{Cd}$ with respect to the other sites (Fig. 6). Moreover, Cd levels decreased gradually by going from the negative (Brown Bay (D) and Punta Moat (G) sites) to the positive semiaxis (Ushuaia Harbour site (B) (Fig. 6).

Ecosystems comparison

With the aim of comparing ecosystems (Beagle Channel vs. Tyrrhenian Sea), we applied the Johnson's method (Conti and Finoia 2010) to the results obtained with $P$. caerulea-a well known metal biomonitor-sampled along a $800 \mathrm{~km}$ transect in the Tyrrhenian Sea. The results of this study are shown in Figs. 7, 8, 9, 10, 11.

Considering the baseline metal levels (i.e., natural ranges) in Italian seas, in ecosystems with medium-low, and very low levels of contamination (Conti and Finoia 2010) we observe that all metal levels in the Beagle Channel are within the normality range limits of metals' concentration (Figs. 7, 8, 9, 10, 11). Some assumptions on these findings will be presented with the discussion. 
Fig. 6 LDA on PCA results of sampling station factors for $N$. magellanica metal data (concentrations determined in viscera). Composed plot: (top left): the plot of the canonical weights; (middle left) the plot of canonical correlations between variates and the first two canonical discriminant functions; (bottom left); the eigenvalues bar chart; (bottom centre): the plot of PCA factors into LDA plane; (bottom right): the gravity centers of classes; [main graph]: the projection of the canonical scores with ellipses and gravity center of classes. The $75.5 \%$ of total variability is explained

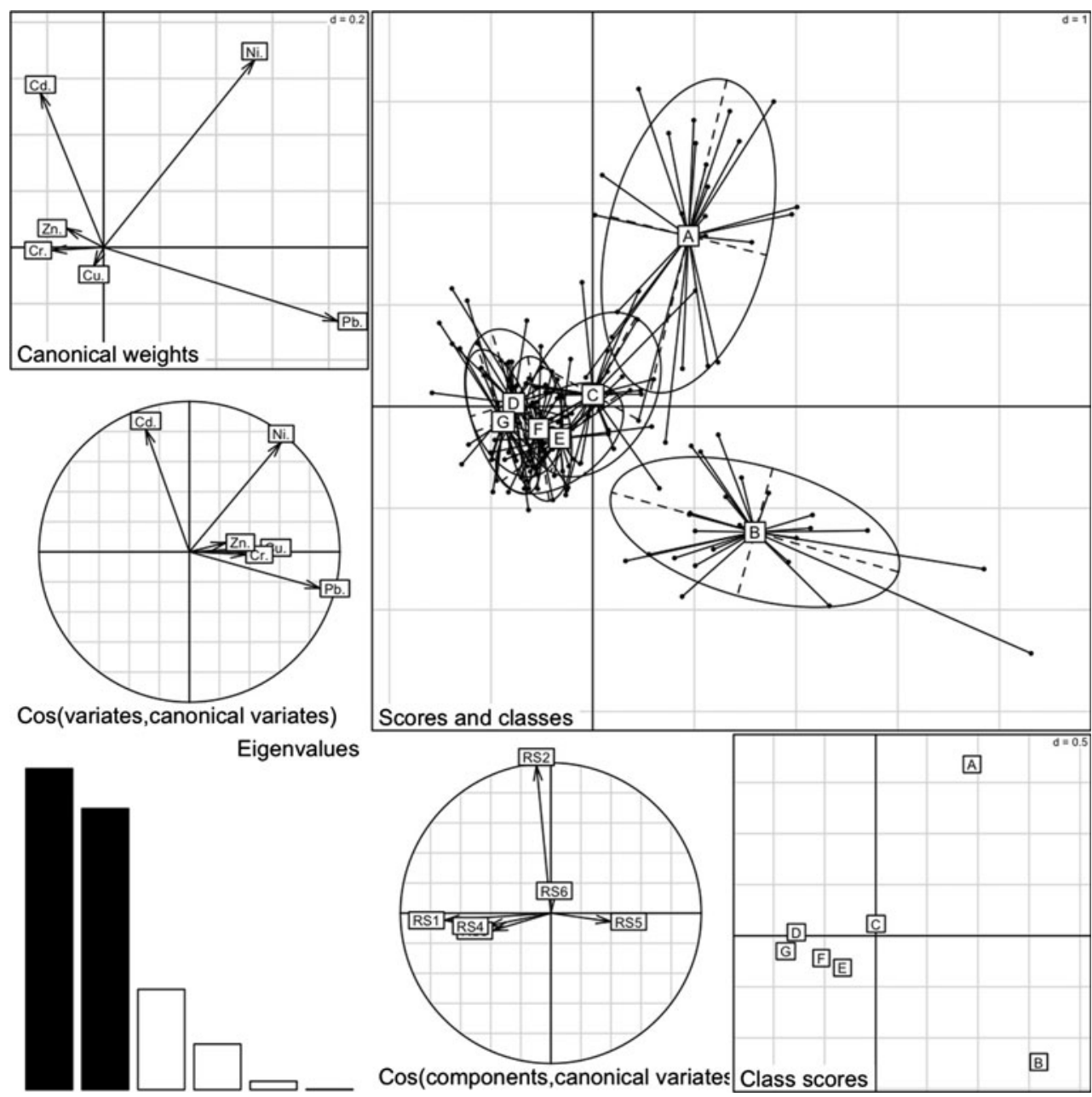

Beagle Channel as a baseline ecosystem for these pollutants (Conti et al. 2011).

Another comparison was performed between the mean muscle levels of $\mathrm{Cd}, \mathrm{Cu}, \mathrm{Pb}$ and $\mathrm{Zn}$ found in the patellid limpet Nacella concinna in ice-impacted intertidal areas in Antarctica (Ahn et al. 2002, 2003; Curtosi et al. 2010; De Moreno et al. 1997) with those reported in this work. It was observed that, with only one exception, the metals levels in the Beagle Channel are clearly lower than those of Antarctica sites (see Table 2). It is not surprising since the surroundings of Antarctic Stations present several sources of pollution (Vodopivez et al. 2008) whilst Beagle Channel shows quite low industrial development in sites different of Ushuaia City (Conti et al. 2011).

Comparing our mean levels of $\mathrm{Cd}, \mathrm{Cr}, \mathrm{Cu}, \mathrm{Pb}$ and $\mathrm{Zn}$ (i.e., 8.22, 3.16, 15.16, 1.23, $96.2 \mu \mathrm{g} \mathrm{g}^{-1}$ respectively) in $N$. magellanica viscera samples with those of $N$. concinna (viscera samples) collected in ice-impacted sites in Antarctica and other patellid limpets collected in Greece (Table 2), we clearly observe that our data are always significantly lower than the others. 


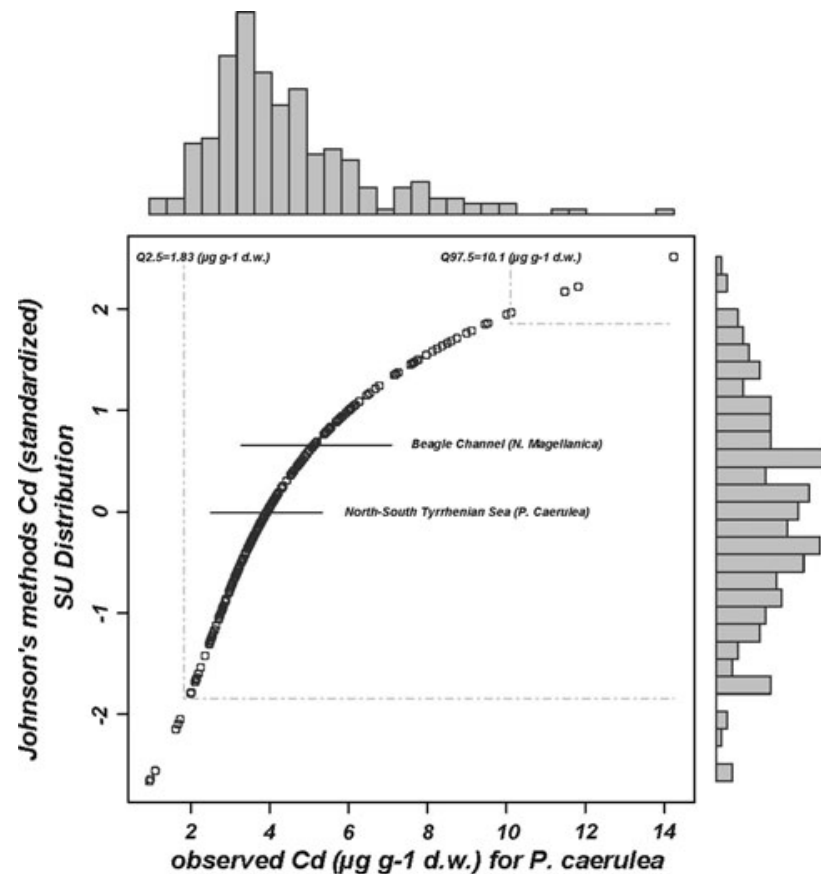

Fig. 7 Cd distribution in $P$. caerulea samples in the Tyrrhenian Sea (800 km transect) compared with $N$. magellanica samples collected in the Beagle Channel (170 km of coast). Concentration values ( $x$-axis); standardized values according to Johnson's method ( $y$-axis); range (Q2.5-Q97.5 percentile) of metal concentration values (grey dotted line); median values \pm MAD (Median Absolute Deviation) determined for the two ecosystems; histograms of observed values (top side); histograms of calculated values according to Johnson (right side)

The comparison of metal accumulation in whole tissues of some patellid limpets of different geographical areas in the world was also performed and it is displayed in Table 2.

Mean Cd levels in the muscle and viscera of $N$. magellanica (3.97; $8.22 \mu \mathrm{g} \mathrm{g}^{-1}$ respectively) in the Beagle Channel (2005 and 2007 sampling campaigns) resulted quite high as above reported (subsection Variation of the metal contamination). Figure 2 (muscle) shows higher levels of $\mathrm{Cd}$ in Lapataia Bay (site A) and Punta Moat (site G) compared with the other sites. This agrees with our previous finding that is the quite high $\mathrm{Cd}$ bioavailability present in the Beagle Channel seawater, studied by using a bivalve Mytilus chilensis as biomonitor (Conti et al. 2011). The higher Cd biovailability measured in the two sampling campaigns (2005 and 2007) could be ascribed to the chemical environment which could leave a higher amount of bioavailable cadmium in seawater (Conti et al. 2011; Muse et al. 2006). However, the total soluble cadmium resulted no detectable with our analytical method, this assumption needs additional investigation. Another possible reason could be the presence of some concomitant able to trigger $\mathrm{Cd}$ accumulation (Conti et al. 2011).

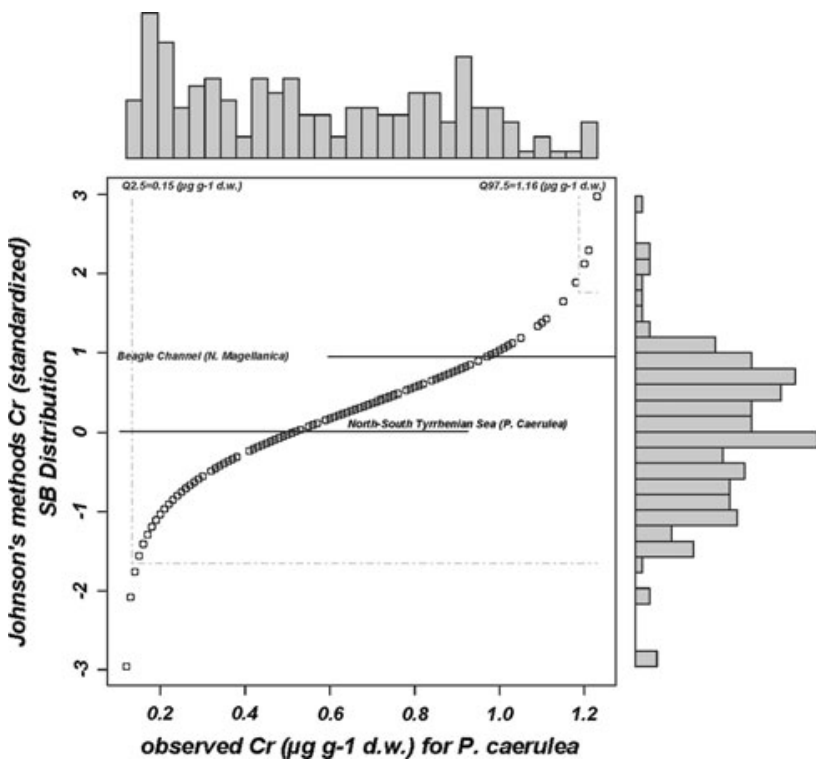

Fig. $8 \mathrm{Cr}$ distribution in $P$. caerulea samples in the Tyrrhenian Sea (800 km transect) compared with $N$. magellanica samples collected in the Beagle Channel (170 km of coast). Concentration values ( $x$-axis); standardized values according to Johnson's method ( $y$-axis); Range (Q2.5-Q97.5 percentile) of metal concentration values (grey dotted line); median values \pm MAD (Median Absolute Deviation) determined for the two ecosystems; histograms of observed values (top side); histograms of calculated values according to Johnson (right side)

On the other hand our results again confirm that there are different accumulation levels depending on the sampling site which could be attributed to different speciation of Cd in each site (Muse et al. 2006).

In relation to the intake, Nacella species constitutes a popular food in the Beagle Channel areas together with Mytilus species. As above reported they are well distributed in the Beagle Channel. With regard to the intake of trace metals it is of relevance to control the levels of toxic metals such as cadmium and lead. Cadmium is a non essential element and it is highly toxic. The effects of acute poisoning in humans are of high significance and can affect blood pressure, kidney damage, destruction of red blood cells and testicular tissue (Manahan 2000). However, and taking into account the current consumption of $N$. magellanica in the zone, presently, for $\mathrm{Cd}$ and $\mathrm{Pb}$, the health risks of $N$. magellanica consumers can be excluded.

Seawater analysis of all the metals in solution was carried out in order to determine the concentration factors (CFs) and to test the ability of $N$. magellanica as metal bioaccumulator (Table 1). Note that accumulation values soften the differences amongst sites and amongst periods as they account for history of contamination and do not reflect an unexpected change in a particular moment. Moreover, it is worth noting that metal concentrations in seawater depend on several conditions such as salinity, physicochemical parameters, 


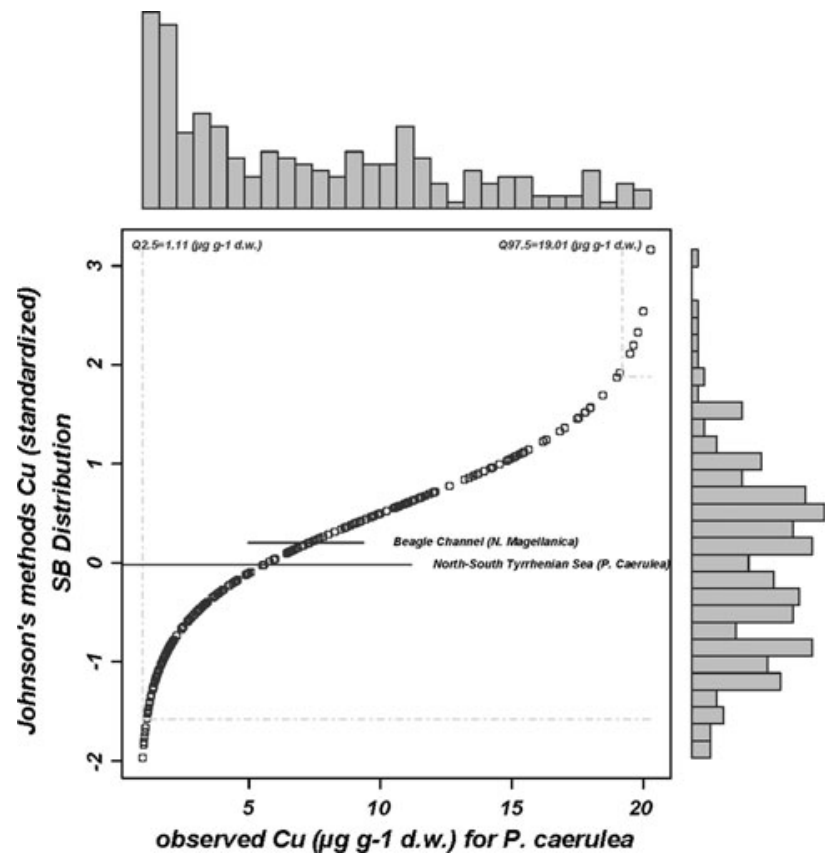

Fig. $9 \mathrm{Cu}$ distribution in $P$. caerulea samples in the Tyrrhenian Sea (800 km transect) compared with $N$. magellanica samples collected in the Beagle Channel (170 km of coast). Concentration values ( $x$-axis); standardized values according to Johnson's method ( $y$-axis); Range (Q2.5-Q97.5 percentile) of metal concentration values (grey dotted line); median values \pm MAD (Median Absolute Deviation) determined for the two ecosystems; histograms of observed values (top side); histograms of calculated values according to Johnson (right side)

sampling conditions, humic substances, etc.; and this is why they have to be interpreted with caution (Turner et al. 2008; Güell et al. 2008; Conti et al. 2010).

Mean soluble metal levels in the Beagle Channel seawaters were low (Table 1), in particular $<18$ and $1,176 \pm 1,243 \mathrm{ng} \mathrm{L}^{-1}$ for $\mathrm{Cd}$ and $\mathrm{Pb}$ respectively. These levels are well below than those proposed by the World Health Organization (WHO) and the U.S. Environmental Protection Agency since the maximum tolerable levels, that are 10 and $50 \mu \mathrm{g} \mathrm{L}^{-1}$ for $\mathrm{Cd}$ and $\mathrm{Pb}$ respectively (Süren et al. 2007).

Comparing $\mathrm{Cd}, \mathrm{Cu}$ and $\mathrm{Zn}$ levels in the Beagle Channel seawater (soluble fraction) with other studies, they resulted to be clearly lower than those of medium-low contaminated and uncontaminated sites in Tyrrhenian areas (Campanella et al. 2001; Conti and Cecchetti 2003; Conti et al. 2010). Generally, the metal levels in the Beagle Channel are low; a fully discussion on these results is reported elsewhere (Conti et al. 2011).

CFs were calculated as above described. This study evidences that viscera samples in $N$. magellanica accumulate metals at clearly higher levels than those determined in muscle samples (Table 1). Very high CFs were determined in viscera for all the analyzed metals in

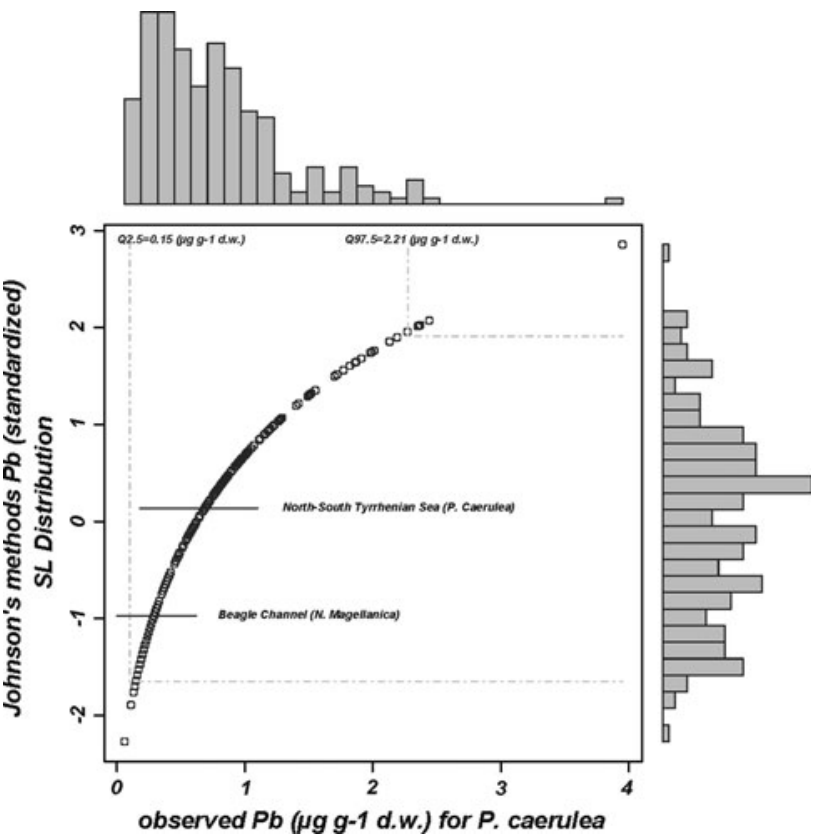

Fig. $10 \mathrm{~Pb}$ distribution in $P$. caerulea samples in the Tyrrhenian Sea (800 km transect) compared with $N$. magellanica samples collected in the Beagle Channel (170 km of coast). Concentration values ( $x$-axis); standardized values according to Johnson's method (y-axis); Range (Q2.5-Q97.5 percentile) of metal concentration values (grey dotted line); median values \pm MAD (Median Absolute Deviation) determined for the two ecosystems; histograms of observed values (top side); histograms of calculated values according to Johnson (right side)

N. magellanica (Table 1). In particular the CF values for $\mathrm{Cd}$ and $\mathrm{Zn}$ in viscera samples were extremely high $\left(471.7 \times 10^{3}\right.$ and $129.4 \times 10^{3}$ respectively $)$ confirming the great ability of Nacella species to accumulate very high levels of metals. Thus, in N. magellanica, $\mathrm{Cd}$ was the most abundant metal followed by $\mathrm{Zn}$. This agrees with our previous studies conducted in Italian seas were a patellid limpet (Patella caerulea) resulted always the strongest accumulator of $\mathrm{Cd}$ followed by $\mathrm{Zn}$ (Campanella et al. 2001; Conti and Cechetti 2003; Conti et al. 2007a, 2010). Moreover, comparing N. magellanica CFs with those of bivalve metal data (M. chilensis) determined in the same sites in our previous study (Conti et al. 2011), we observe that $\mathrm{Cd}, \mathrm{Cu}, \mathrm{Ni}, \mathrm{Pb}$ and $\mathrm{Zn} \mathrm{CFs}$ in viscera were higher in the herbivorous gastropods than in bivalves.

Even if CFs could be influenced by the passage of contaminant through the trophic chain (Ahn et al. 2002; Wang and Ke 2002), our data confirms the high ability of Nacella as a very good metal bioaccumulator, which is consistent with the herbivorous diet of the limpet.

From the displayed results (i.e., Variation of the metal contamination) we can conclude that the metal distribution among sites is not univocal and, moreover, that none of these sites is clearly contaminated than the others. No one site shows significant high levels of the all studied metals in 


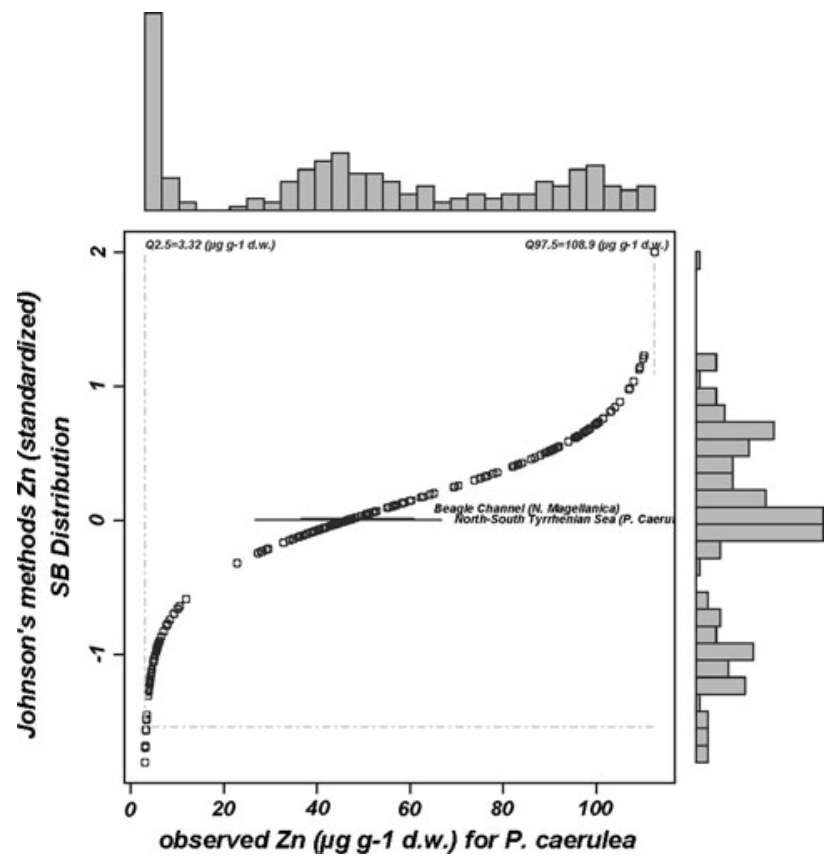

Fig. $11 \mathrm{Zn}$ distribution in $P$. caerulea samples in the Tyrrhenian Sea (800 km transect) compared with $N$. magellanica samples collected in the Beagle Channel (170 km of coast). Concentration values ( $x$-axis); standardized values according to Johnson's method (y-axis); Range (Q2.5-Q97.5 percentile) of metal concentration values (grey dotted line); median values \pm MAD (Median Absolute Deviation) determined for the two ecosystems; histograms of observed values (top side); histograms of calculated values according to Johnson (right side)

N. magellanica. This finding also agrees with our previous study in which M. chilensis was used as a biomonitor. Thus, the expected hypothesis of the Ushuaia Harbour as being the most contaminated site should be again reconsidered. However, the obtained results for the study of sites classification by LDA on PCA factors (see previous section), demonstrate that the Ushuaia Harbour (B) has higher $\mathrm{Pb}, \mathrm{Cu}$, $\mathrm{Cr}$ e $\mathrm{Zn}$ concentrations and lower $\mathrm{Cd}$ concentrations with respect to the other sites. On the contrary, the PCA and LDA analysis clearly show that the higher bioavailability of $\mathrm{Cd}$ and $\mathrm{Ni}$ is present in the Lapataia Bay (A) with respect to the other sites. Generally, at present, it is difficult to found the direct source of these contaminants along $170 \mathrm{~km}$ of the Beagle Channel coast.

The ecosystems' comparison study (see "Results" section) is of relevance and, to a certain extent, not expected because the Beagle Channel ecosystem resulted to be not much dissimilar to the North-South Tyrrhenian Seas (Italy). In fact, the Beagle Channel ecosystem matches the reference range limits of metals' concentration of NorthSouth Tyrrhenian Seas (Italy) (Figs. 7, 8, 9, 10, 11). Thus, from this finding we can infer that the marine ecosystems in Patagonia are comparable with those of North-South Tyrrhenian seas.

In particular, $\mathrm{Zn}$ concentrations between the ecosystems studied resulted to be very similar (M-W, $W=20,834$, $p$ value $=0.4775)($ Fig. 11).

Comparing $N$. magellanica $\mathrm{Pb}$ levels in the Beagle Channel with those obtained in North-South Tyrrhenian (P. caerulea) sea ecosystems we observe significant lower $\mathrm{Pb}$ levels in the Beagle Channel ecosystem as expected $(\mathrm{M}-\mathrm{W}, W=11,989, p$ value $<0.001$ ) (Fig. 10).

Surprisingly, for the other metals (i.e., $\mathrm{Cd}, \mathrm{Cr}$ and $\mathrm{Cu}$ ), the levels in N. magellanica resulted always significantly higher in the Beagle Channel than those of the NorthSouth Tyrrhenian ecosystems (M-W, $p<0.001)$ (Figs. 7, $8,9)$. This is a matter of interesting discussion and, as previously discussed (Conti et al. 2011) it can be connected with the metal biogeochemistry in coastal waters (Price and Morel 1990).

\section{Conclusions}

$N$. magellanica turned out to be very relevant for the study of coastal areas with very low levels of contamination considering its aptitude to accumulate from tens (muscle) to hundreds of thousand times (viscera) higher levels of metals than those present in the seawater soluble fraction. Our results, as expected, clearly show higher metal bioaccumulation levels in viscera than in muscle of Nacella (P)magellanica.

Concerning the low consumption of these mollusks by humans, toxic metals do not represent a risk for health at present. Besides, giving the average intake in the area, intoxication seems very unlikely.

In the case of essential metals, copper ingestion exceeds with the amount proposed by the Food and Nutrition Board, the same with the intake of $\mathrm{Zn}$ which is much higher than that established by FAO/WHO. This confirms the nutritional relevance of these mollusks. Ni intake, on the contrary, is quite low according to the Food and Nutrition Board.

The analysis of variation of contamination between sampling periods, again confirm that there is not univocal distribution of metals' contamination in the Beagle Channel over time.

The multivariate study confirmed the high $\mathrm{Cd}$ bioavailability in the Lapataia Bay. Surprisingly, the probabilistic approach here employed for comparison among ecosystems showed that $\mathrm{Cd}, \mathrm{Cr}$ and $\mathrm{Cu}$ levels in $N$. magellanica were always significantly higher in the Beagle Channel than those of the North-South Tyrrhenian. This aspect needs further investigation. 
Table 2 Selected references of metal concentrations in limpets ( $\mu \mathrm{g} \mathrm{g}^{-1}$ dry weight) from different geographical areas (mean values and ranges, values in parenthesis are given as fresh weight)

\begin{tabular}{|c|c|c|c|c|c|c|c|c|}
\hline & Sites & $\mathrm{Cd}$ & $\mathrm{Cr}$ & $\mathrm{Cu}$ & $\mathrm{Ni}$ & $\mathrm{Pb}$ & $\mathrm{Zn}$ & References \\
\hline \multicolumn{9}{|l|}{ Species (muscle) } \\
\hline Nacella magellanica & $\begin{array}{l}\text { Beagle Channel, Argentina ( } 7 \text { sites } \\
\text { along } 170 \mathrm{~km} \text { of coast) }\end{array}$ & 3.97 & 0.20 & $<4.0$ & $<0.30$ & $<0.10$ & 30.7 & This work \\
\hline Nacella concinna & King George Island (Antarctica) & 2.16 & 1.1 & 3.3 & & 0.47 & 50.6 & Ahn et al. (2002) \\
\hline Nacella concinna & Potter Cove (Antarctica) & 25.3 & $<0.01$ & 16.4 & & 0.45 & 44.9 & Curtosi et al. (2010) \\
\hline Nacella concinna & $\begin{array}{l}\text { King George Island (Antarctica) } \\
\text { Site } 1\end{array}$ & 18.1 & & 9.13 & & & 67.5 & De Moreno et al. $\left(1997^{\mathrm{a}}\right)$ \\
\hline Nacella concinna & $\begin{array}{l}\text { King George Island (Antarctica) } \\
\text { Site } 2\end{array}$ & 14.2 & & 11.2 & & & 68.2 & De Moreno et al. $\left(1997^{\mathrm{a}}\right)$ \\
\hline Nacella concinna & Anvers Island (Antarctica) Site 3 & 9.6 & & 5.0 & & & 87.7 & De Moreno et al. $\left(1997^{\mathrm{a}}\right)$ \\
\hline Nacella concinna & Anvers Island (Antarctica) Site 4 & 11.7 & & 7.86 & & & 62.8 & De Moreno et al. $\left(1997^{\mathrm{a}}\right)$ \\
\hline \multicolumn{9}{|l|}{ Species (viscera) } \\
\hline Nacella magellanica & Beagle Channel, Argentina & 8.22 & 3.16 & 15.16 & 7.63 & 1.23 & 96.2 & This work \\
\hline Nacella concinna & King George Island (Antarctica) & 15.7 & 4.47 & 79.5 & & 5.04 & 118 & Ahn et al. (2002) \\
\hline Nacella concinna & $\begin{array}{l}\text { King George Island (Antarctica) } \\
\text { Site } 1\end{array}$ & 23 & & 87.4 & & & 189.3 & De Moreno et al. $\left(1997^{b}\right)$ \\
\hline Nacella concinna & $\begin{array}{l}\text { King George Island (Antarctica) } \\
\text { Site } 2\end{array}$ & 26.5 & & 85.2 & & & 163 & De Moreno et al. $\left(1997^{b}\right)$ \\
\hline Nacella concinna & Anvers Island (Antarctica) Site 3 & 18.3 & & 22.2 & & & 186 & De Moreno et al. $\left(1997^{\mathrm{b}}\right)$ \\
\hline Nacella concinna & Anvers Island (Antarctica) Site 4 & 30.2 & & 25.6 & & & 167 & De Moreno et al. $\left(1997^{\mathrm{b}}\right)$ \\
\hline Patella caerulea & Evoikos Bay, Greece & & 6.15 & 27.1 & & & 180 & Nicolaidou and Nott (1990) \\
\hline \multicolumn{9}{|l|}{ Species (whole tissue) } \\
\hline Nacella magellanica & $\begin{array}{l}\text { Beagle Channel, Argentina } \\
\text { (Ushuaia city coastline) }\end{array}$ & 1.81 & & 6.15 & & 4.78 & 80.1 & Comoglio et al. $\left(2011^{\mathrm{c}}\right)$ \\
\hline Nacella deaurata & Magellan Strait, Chile & & & 7.99 & & & 56.7 & Astorga España et al. $\left(2005^{\mathrm{d}}\right)$ \\
\hline Nacella deaurata & Magellan Strait, Chile & 3.40 & & & 5.33 & & & Astorga España et al. $\left(2004^{\mathrm{d}}\right)$ \\
\hline Patella caerulea & Favignana Island, Sicily (Italy) & 4.41 & 0.3 & 1.7 & & 0.2 & 5 & Campanella et al. (2001) \\
\hline Patella caerulea & Gulf of Gaeta, central Italy & 3.54 & 0.85 & 14.3 & & 0.95 & 100.8 & Conti and Cecchetti (2003) \\
\hline Patella caerulea & Ustica Island, Sicily (Italy) & 4.7 & 0.56 & 6.3 & & 1.02 & 51 & Conti et al. (2007a) \\
\hline Patella caerulea & Linosa Island, Sicily (Italy) & 3.57 & 0.42 & 5.87 & & 1.01 & 43.2 & Conti et al. (2010) \\
\hline
\end{tabular}

${ }^{a}$ Data from this paper were converted to dry weight using the wet weight/dry weight $=7.94$ (muscle)

${ }^{\mathrm{b}}$ Data from this paper were converted to dry weight using the wet weight/dry weight $=5.15$ (viscera)

${ }^{\mathrm{c}}$ Data from this paper were properly averaged

${ }^{\mathrm{d}}$ Wet weight/dry weight $=6.66$ calculated from mean moisture percent declared by authors

The main concluding remarks with respect to the area under study are: (a) the hypothesis of Ushuaia Harbour as being the most contaminated site amongs the seven sampling locations must be reconsidered; (b) apart from cadmium, the results support the hypothesis that the Beagle Channel could be a background reference ecosystem for marine areas in the world (c) The naturality metal levels between the Beagle Channel ecosystem and Tyrrhenian low-contaminated and uncontaminated ecosystems (Italy) resulted surprisingly comparable.

Acknowledgments We are grateful to Javier Omar Giordano and his team for their support during our stays in Tierra del Fuego. This work was financially supported by project prot. C26F09TP2K-2009, project prot. C26A104LN5-2010 of Sapienza, University of Rome,
Italy, University of Buenos Aires (UBA) and National Research Council of Argentina (CONICET).

\section{References}

Ahn I-Y, Kang J, Kim D-Y (1999) A preliminary study on heavy metals in the Antarctic limpet, Nacella concinna (Strebel, 1908) (Gastropoda: Patellidae) in an intertidal habitat on King George Island. Korean J Polar Pollut 111:117-126

Ahn I-Y, Kim K-W, Choi HJ (2002) A baseline study on metal concentrations in the Antarctic limpet Nacella concinna (Gastropoda: Patellidae) on King George Island: variations with sex and body parts. Mar Pollut Bull 44:421-431

Ahn I-Y, Choi HJ, Kim K-W (2003) Heavy metal pollution monitoring at King Sejong Station, King George Island, Antarctica. Ocean Polar Res 25:645-652 
Astorga España MS, Rodríguez Rodríguez EM, Díaz Romero C (2004) Manganese, nickel, selenium and cadmium in molluscs from the Magellan Strait, Chile. Food Addit Contam 21:768-773

Astorga España MS, Rodríguez Rodríguez EM, Díaz Romero C (2005) Sodium, K, Ca, Mg, Fe, Cu and $\mathrm{Zn}$ concentrations in molluscs from the Magellan Strait (Chile): their contribution to dietary intake. Int J Food Sci Nutr 56:337-347

Bocca B, Conti ME, Pino A, Mattei D, Forte G, Alimonti A (2007) Simple, fast, and low contamination microwave-assisted digestion procedures for the determination of chemical elements in biological and environmental matrices by sector field ICP-MS. Int J Environ Anal Chem 87:1111-1123

Campanella L, Conti ME, Cubadda F, Sucapane C (2001) Trace metals in seagrass, algae and molluscs from an uncontaminated area in the Mediterranean. Environ Pollut 111:117-126

Chessel D, Dufour A, Thioulouse J (2004) The ADE4 package. I. One-table methods. R News 4:5-10

Comoglio L, Amin O, Botté S, Marcovecchio J (2011) Use of biomarkers in resident organisms as a tool for environmental monitoring in a cold coastal system, Tierra del Fuego Island. Ecotox Environ Saf 74:382-393

Conti ME (ed) (2008) Biological monitoring: theory and applications. Bioindicators and biomarkers for environmental quality and human exposure assessment. The sustainable world, vol 17. WIT Press, Southampton

Conti ME, Cecchetti G (2003) A biomonitoring study: trace metals in algae and molluscs from Tyrrhenian coastal areas. Environ Res 93:99-112

Conti ME, Finoia MG (2010) Metals in molluscs and algae: a northsouth Tyrrhenian sea baseline. J Hazard Mater 181:388-392

Conti ME, Mecozzi M (2008) Multivariate approaches to biomonitoring studies. In: Conti ME (ed) Biological monitoring: theory and applications. The sustainable world, vol 17. WIT Press, Southampton, pp 213-226

Conti ME, Tudino MB, Muse JO, Cecchetti GF (2002) Biomonitoring of heavy metals and their species in the marine environment: the contribution of atomic absorption spectroscopy and inductively coupled plasma spectroscopy. Res Trends Appl Spectrosc 4: 295-324

Conti ME, Iacobucci M, Cecchetti G (2005) A statistical approach applied to trace metal data from biomonitoring studies. Int $\mathrm{J}$ Environ Pollut 23:29-41

Conti ME, Stripeikis J, Iacobucci M, Cucina D, Cecchetti G, Tudino MB (2006) Trace metals in molluscs from the Beagle Channel (Argentina): a preliminary study. WIT Trans Ecol Environ 99:473-483

Conti ME, Iacobucci M, Cecchetti G (2007a) A biomonitoring study: trace metals in seagrass, algae and molluscs in a marine reference ecosystem (Southern Tyrrhenian Sea). Int J Environ Pollut 29:308-332

Conti ME, Iacobucci M, Cucina D, Mecozzi M (2007b) Multivariate statistical methods applied to biomonitoring studies. Int $\mathrm{J}$ Environ Pollut 29:333-343

Conti ME, Pino A, Botrè F, Bocca B, Alimonti A (2009) Lichen Usnea barbata as biomonitor of airborne elements deposition in the Province of Tierra del Fuego (southern Patagonia, Argentina). Ecotox Environ Saf 72:1082-1089

Conti ME, Bocca B, Iacobucci M, Finoia MG, Mecozzi M, Pino A, Alimonti A (2010) Baseline trace metals in seagrass, algae and molluscs in a southern Tyrrhenian ecosystem (Linosa Island, Sicily). Arch Environ Contam Toxicol 58:79-95

Conti ME, Stripeikis J, Finoia MG, Tudino MB (2011) Baseline trace metals in bivalve molluscs from the Beagle Channel, Patagonia (Argentina). Ecotoxicology 20:1341-1353

Conti ME, Finoia MG, Bocca B, Mele G, Alimonti A, Pino A (2012) Atmospheric background trace elements deposition in Tierra del
Fuego region (Patagonia, Argentina), using transplanted Usnea barbata lichens. Environ Monit Assess 184:527-538

Curtosi A, Pelletier E, Vodopivez C, St Louis R, Mac Cormack WP (2010) Presence and distribution of persistent toxic substances in sediments and marine organisms of Potter Cove, Antarctica. Arch Environ Contam Toxicol 59:582-592

De Moreno JEA, Gerpe MS, Moreno VJ, Vodopivez C (1997) Heavy metals in Antarctic organisms. Polar Biol 17:131-140

Deudero S, Box A, Tejada S, Tintoré J (2009) Stable isotopes and metal contamination in caged marine mussel Mytilus galloprovincialis. Mar Pollut Bull 58:1025-1031

Giovanardi F, Finoia MG, Russo S, Amori M, Di Lorenzo B (2006) Coastal waters monitoring data: frequency distributions of the principal water quality variables. J Limnol 65:65-82

Güell R, Aragay G, Fontàs C, Anticó E, Merkoçi A (2008) Sensitive and stable monitoring of lead and cadmium in seawater using screen-printed electrode and electrochemical stripping analysis. Anal Chim Acta 627:219-224

Johnson NL (1949) System of frequency curves generated by methods of translation. Biometrika 36:149-175

Manahan SE (2000) Environmental chemistry, 7th edn. Lewis Publishers, London

Morriconi E (1999) Reproductive biology of the limpet Nacella (P.) deaurata (Gmelin, 1791) in Bahia Lapataia (Beagle Channel). Sci Mar 63(Suppl.):417-426

Muse JO, Carducci CN, Stripeikis JD, Tudino MB, Fernández FM (2006) A link between lead and cadmium kinetic speciation in seawater and accumulation by the green alga Ulva lactuca. Environ Pollut 141:126-130

Narin I, Soylak M (2003) The uses of 1-(2-pyridylazo) 2-naphtol (PAN) impregnated Ambersorb 563 resin on the solid phase extraction of traces heavy metal ions and their determinations by atomic absorption spectrometry. Talanta 60:215-221

Nicolaidou A, Nott JA (1990) Mediterranean pollution from a Ferronickel smelter: differential uptake of metals by some gastropods. Mar Pollut Bull 21:137-143

Pedro J, Stripeikis J, Bonivardi A, Tudino M (2008) Determination of tellurium at ultra-trace levels in drinking water by on-line solid phase extraction coupled to graphite furnace atomic absorption spectrometer. Spectrochim Acta B 63:86-91

Pino A, Alimonti A, Botrè F, Minoia C, Bocca B, Conti ME (2007) Determination of twenty five elements in lichens by sector field inductively coupled plasma mass spectrometry and microwave assisted acid digestion. Rapid Commun Mass Spectrosc 21:1900-1906

Pino A, Alimonti A, Conti ME, Bocca B (2010) Iridium, platinum and rhodium baseline concentration in lichens from Tierra del Fuego (South Patagonia, Argentina). J Environ Monitor 12:1857-1863

Price NM, Morel FMM (1990) Cadmium and cobalt substitution for zinc in a marine diatom. Nature 344:658-660

Rainbow PS, Phillips DJH (1993) Cosmopolitan biomonitors of trace metals. Mar Pollut Bull 26:593-601

Süren E, Yilmaz S, Türcoglu M, Kaya S (2007) Concentrations of cadmium and lead heavy metals in Dardanelles seawater. Environ Monit Assess 125:91-98

Turner A, Pedroso SS, Brown MT (2008) Influence of salinity and humic substances on the uptake of trace metals by the marine macroalga, Ulva lactuca: experimental observations and modeling using WHAM. Mar Chem 110:176-184

Vodopivez C, Mac Cormack W, Villamil E, Curtosi A, Pelletier E, Smichowski P (2008) Evidence of pollution with hydrocarbons and heavy metals at the surrounding of Jubany Station. The Antarctic ecosystem of Potter Cove, King-George Island (Isla 25 de Mayo). Ber Polarforsch 571:357-364

Wang W-X, Ke C (2002) Dominance of dietary intake of cadmium and zinc by two marine predatory gastropods. Aquat Toxicol $56: 153-165$ 
Wheeler B (2009). SuppDists: supplementary distributions. R package version 1.1-8. http://CRAN.R-project.org/package=Supp Dists [bwheelerg@gmail.com]
Zhou F, Guo H, Hao Z (2007) Spatial distribution of heavy metals in Hong Kong's marine sediments and their human impacts: a GISbased chemometric approach. Mar Pollut Bull 54:1372-1378 